\title{
The Role of Religious Institutions in Preventing Radical Leftism
}

\author{
Mohammad Syairozi Dimyathi Ilyas \\ Syarif Hidayatullah State Islamic University \\ Jakarta, Indonesia \\ syairozi.dimyathi@uinjkt.ac.id
}

\begin{abstract}
This article examines the role of Ali Mustafa Yaqub as a moderate Indonesian hadith expert in several national issues related to the issue of the emergence and development of radical movements through the educational institution he founded, DarusSunnah. This article draws primary data from DarusSunnah educational institution's academic documents through printed books or information on the official website, as well as the results of an interview obtained from one of DarusSunnah's leaders. This article concludes that the role of educational institutions in counteracting radical understanding and reviving moderate values is very important because educational institutions are places for students to get information that will live in ideology for the rest of their lives. DarusSunnah, founded by Ali Mustafa Yaqub, has implemented an anti-radical education system that has proven to give birth to alumni who are active in the community to tackle radical thinking. This is done through four aspects, namely curriculum, learning methods, inculcation of character, and educators.
\end{abstract}

Keywords: the institutions of religious education, the prevention of radicalism, anti-radical education

\section{INTRODUCTION}

Terrorism is not a matter of who the perpetrators, groups, and networks are. However, more than that terrorism is an act that has roots of belief, doctrine, and ideology that can attack people's consciousness. The flourishing of terrorism depends on the land where it grows and develops. If he lives in arid lands, terrorism is difficult to find a place, on the contrary, if he lives on fertile land he will quickly develop. The fertile field, according to Hendropriyono, is a society polluted by extreme fundamentalism or religious radicalism [1].

Radicalism is the embryo of the birth of terrorism. Radicalism is an attitude that craves total change and is revolutionary by overturning existing values drastically through violence and extreme actions. Several characteristics can be recognized from a radical attitude and understanding. 1) intolerant (do not want to respect the opinions \& beliefs of others), 2) fanatics (always feel right themselves; think others are wrong), 3) exclusive (distinguish themselves from Muslims in general) and 4) revolutionary (tend to use violent means to reach the goal) [2].

Having a radical attitude and understanding does not necessarily make a person fall into terrorism understanding and action. Other factors motivate

\author{
Fatihunnada \\ Syarif Hidayatullah State Islamic University \\ Jakarta, Indonesia \\ fatihunnada@uinjkt.ac.id
}

someone to join the terrorist network. Motivation is caused by several factors. First, domestic factors, namely domestic conditions such as poverty, injustice or feeling disappointed with the government. Second, international factors, namely the influence of the foreign environment that provides the driving force for the growth of religious sentiments such as global injustice, arrogant foreign policy, and modern imperialism of the superpower. Third, cultural factors that are strongly associated with shallow religious understanding and narrow and lexical interpretation of the holy book (harfiyah). Radical attitudes and understandings and motivated by various factors above often make a person choose to join terrorism actions and networks.

The index of radicalism in Indonesia as stated by Wuryanto (2011) is already above normal. Indonesia is a country with a high level of diversity and a place of differences in ethnicity, race, religion, customs, etc. Radical actions arise because radical individuals/groups cannot accept differences, even consider the diversity that occurs in society is considered as a threat to the existence of radical groups. Therefore to maintain the existence of radical groups, they must eliminate other groups that do not agree. Radicalism in the name of religion unconsciously hates followers to hate the teachings of their religion. Therefore, if there are violent actions in the name of religion, what is wrong is one's perception of the teachings of the religion they hold [3].

In 2016, the Wahid Foundation and LSI conducted a study that resulted in 11 million $(7.7 \%)$ Indonesian Muslim communities willing to take radical action [4] The potential of radicalism is not only attacking the general public, but even religious groups also do not escape the spread of radicalism. In 2016, according to BNPT data, 19 Islamic boarding schools were indicated to spread radicalism [5].

This shows that educational institutions become a very potential place for the inculcation of radical understanding because educational institutions are places for doctrine an ideology. No wonder, if PPIM Jakarta launched research in 2017 that $58.5 \%$ of students and students have radical thoughts, even though only $7 \%$ have ever carried out radicalism [6].

The relationship between radicalism and educational institutions can be seen in 3 (three) aspects. First, educators play an active role in shaping 
students' radical paradigms; Second, Islamic Religious Education in schools and colleges is considered not to open a comprehensive Islamic insight, but to close the sensitivity to diversity; and Third, freedom of internet access has a big influence on the radical attitude of students and students.

In addition, religious education institutions are considered to have a favourite character for the cultivation of ideological in 3 (three) cases. First, incubators for violent extremism and jihad factories; Second, violence and hatred (an ideology of intolerance, violence, and hate); And thirdly, indoctrinating them (Muslim students) with a hatred for the West, the ideology of intolerance.

\section{METHOD}

This research is qualitative with data analysis taken from the field which will produce critical arguments [7]. Qualitative becomes relevant because the nature of the problem itself is research that aims to examine the meaning, appreciation, diversity, and aims to understand what is hidden behind the phenomenon.

The primary data source used is a document describing the role of Ali Mustafa Yaqub through DarusSunnah educational institutions contained in DarusSunnah's academic texts, interviews, and so forth. Since this type of research is qualitative research, the authors chose the documentation method as one of the relevant data collection methods, plus interviews to strengthen the data sourced from documents. This method is carried out by collecting documents obtained from the literature and interviews with the leadership of DarusSunnah educational institutions that have a closeness with Ali Mustafa Yaqub, so that the author is expected to get valid information [8]. According to Mohamad Ali, the advantages of interviews as a research tool are: interviews can be carried out to every individual without being limited by age factors or reading ability, the data obtained can be directly known objectivity because it is carried out face-to-face, interviews can be carried out directly to respondents suspected as sources of data, interviews can be carried out with the aim of improving the results obtained and conducting interviews can be more flexible and dynamic because it is done directly so as to minimize misunderstanding [9].

\section{RESULTS AND DISCUSSION}

The assumption that religious education institutions are a potential place to instil radicalism has polluted past history. Islamic boarding schools have proven themselves as one of the institutions that have played a major role in Indonesian history and are known for Islam with a smiling face, especially during independence.

On the other hand, the existence of religious education institutions that are indicated to display radical understanding needs to be anticipated and responded to by the authorities by taking the policy to implement a counter-radical and moderate-based education system. This can be formulated by looking for models of religious education that are already running in Indonesia, such as DarusSunnah.

\section{A. Religious Education Institutions}

There are 4 (four) types of Islamic educational institutions in Indonesia [10]. First, boarding schools with boarding school learning systems in which students are required to settle in boarding schools to instil life character. Pesantren is a classical education system in Indonesia with an emphasis on Islamic materials such as the Koran, Hadith, Jurisprudence, morality, Arabic language studies, and so on.

Second, the madrasa introduced by President Sukarno with the education system that combines the traditional education system with the general subject matter, such as natural education, social education, mathematics, and others.

Third, Islamic schools that grow and develop in urban cities as an alternative for upper-middle economic circles with a modern education system and the portion of general subject matter are more dominant but still colored with religious material such as the superiority of memorizing the Koran and so on.

Fourth, Islamic tertiary institutions are continuing education institutions for pesantren alumni, madrasas, and Islamic schools. The applied education system is the integration of science by instilling critical power over every issue that develops in society.

Islamic schools especially madrasa have been considered as places of indoctrination for Islamic students and militants. Therefore, two root problems must be addressed: First, learning material that is more open, tolerant, and inclusive; and second, teachers who have national, Islamic, and Indonesian-national perspectives [11].

\section{B. Radicalism and Its Deterrence}

Radicalism comes from the word radical, referring to certain circumstances, people, or movements that want social and political change quickly and thoroughly, and not infrequently done using uncompromising and even violent means, not by peaceful means [12]. Radical Islamic movements in Indonesia also experienced rapid progress. This is indicated by the increasing number of followers of these movements each year. These movements have a variety of features, including movements that struggle to uphold Islamic sharia without upholding an Islamic state, movements that seek to make Indonesia an Islamic state and movements that seek to build an Islamic caliphate International and Indonesia becomes part of the caliphate. Some of these movements move with military force, such as Laskar Jihad (LJ) and the Islamic Defenders Front (FPI). And some others move by spreading ideology and thoughts, such as the Indonesian Mujahidin Council (MMI) and HizbutTahrir Indonesia (HTI) [13].

This can be overcome by applying several steps. Among them is counter-radicalization with efforts to instil Indonesian values and non-violent values; and Deradicalization by efforts to moderate radical ideas in 
line with the spirit of moderate Islamic groups and following national missions that strengthen the Republic of Indonesia [14].

Islamic educational institutions in Indonesia have contributed to the formation of the character and culture of Indonesian society. There are 3 (three) important roles that Islamic educational institutions can take to tackle radical understanding in Indonesia. First, education and guidance; Second, social counselling; and third, government partners [15].

From other aspects, there are 2 (two) educational strategies that can be applied by Islamic educational institutions to counter radical understanding among students. First, academic in the curriculum and instructional programs; and second, non-academic activities in extra-curricular activities [16].

\section{Ali Mustafa and Darus Sunnah}

Ali Mustafa Yaqub was born on March 2, 1952 in the village of Kemiri, Subah District, Batang Regency, Central Java. He was included in the hadith figure who was influenced by the Middle East because of his academic experience in the Islamic Studies Program of the Islamic University of Imam Muhammad bin Saud, Riyadh, Saudi Arabia, the Masters Program (King) of King Saud University, Riyadh, and the Doctoral Program (S3) of the University of Nizamia, Hyderabad, India [17]. He was the Professor of the First Hadith of the Institute of Qur'an Sciences in September 1999-28 April 2016.

Ali Mustafa also pioneered DarusSunnah International Institute for Hadith Sciences in 1996 with the first three students. Sometime later, the interest of students to deepen the study of hadith increased and made Ali Mustafa planned to establish a hostel which was then assisted by the Minister of Religion, TarmiziTaher.

DarusSunnah has two educational institutions, namely ma'had 'ali which is a place for students in universities around Ciputat and Jakarta to explore specific hadith science and madrasa which is a place for students at junior high/tsanawiyah and high school/aliyah or equivalent to study the science of Islam which is integrated with general science.

The academic experience at the Tebuireng boarding school, Imam Muhammad bin Saud Islamic University, Riyadh, Saudi Arabia, and Nizamia University, Hyderabad, India provides a variety of thought colors in the figure of Ali Mustafa. This also forms the ideological character of Ali Musafa to adhere to the belief of AhlussunnahWaljamaah, which was pioneered by $\mathrm{NU}$ as the largest base of Islamic community organizations in Indonesia and has a moderate orientation to prevent radical movements in Indonesia [18]. His moderate thinking is inseparable from his experience studying Islam in Islamic boarding schools. The typical social system and tradition style by adopting Ash'ariyah and Maturidiyah theology which is complemented by the Syafi'iyahfigh school make NU-guided Islam capable of being open to every idea and not inclusive [19].
The influence of academic experience in Saudi Arabia appears with its moderate attitude when dealing with the issue of clashes between Indonesian Muslim communities with salafi puritanism. In addressing Aswaja (NU) and Wahabi, he tried to find a meeting point between the two. He does not agree with Wahabis who justify local culture as a case of bid'ah. He also disagrees with the claim of Aswaja (NU) who alleges that Wahabis are a neo-muktazilah group with the propaganda of Islamic purification [20].

\section{The Role of Ali Mustafa Ward off Radicalism}

Ali Mustafa Yaqub is also known as a religious figure who has moderate thinking in understanding Islam. He has published various fresh and enlightening ideas in mass media articles and printed books. An active role in the DarusSunnah educational institution pioneered is also one of the efforts to counter radical ideologies. Based on the interview with Ahmad UbaydiHasbillah who is one of DarusSunnah's leaders, the process of counteracting radicalism in learning in DarusSunnah can be seen in 4 (four) aspects, namely curriculum, learning methods, character building, and teaching staff [21].

\section{E. Curriculum}

The curriculum used by Ma'had 'aliDarusSunnah for teaching materials is a curriculum designed specifically by Ali Mustafa for the deepening of the science of hadith for students, while the curriculum applied by DarusSunnah madrasa is a curriculum with a composition of religious science content that is quite dominant, but accompanied also with general sciences such as mathematics, social education, natural education, Indonesian, English, and others.

Ma'hadaliDarusSunnah uses a curriculum that teaches moderate attitudes and avoids radical thinking that leads to terrorist behavior. This was reflected in some of the teaching material presented. Among them the material of the traditions from the source of the book Sahih al-Bukhari with the discussion of jihad. Jihad, which is the entrance to terrorist groups, is straightened out by understanding the prophetic traditions [22]. Ali Mustafa Yaqub provides a deep understanding of the true concept of Jihad in Islam, so that it can be understood by Indonesian Muslim communities and can maintain the existence of moderate Indonesian Islam, which is not easy to shed the blood of fellow humans based on religious differences. Since several suicide bombings in the Bali I and II bombs, the Marriot Hotel, Ritz Carlton and other suicide bombing cases, Indonesian people have begun to discuss the concept of Jihad in Islam. This theme seems to be a daily consumer topic that needs to be emphasized, given the ideology of Jihad radical groups still survive in Indonesia.

He teaches three striking differences between Jihad and terrorists in Islam, 1) Jihad in Islam is obligatory, while terrorists in Islam are haraam; 2) Jihad in Islam must be based on orders from a leader or president, whereas terrorists can be carried out by individuals without pocketing permission and orders from the 
leader or president; and 3) Jihad in Islam has provisions that must be obeyed, such as not being able to fight civilians who do not participate in fighting Islam, meaning that only those who fight Islam can be fought and killed, whereas terrorists will justify any means to achieve their goals by fight and kill all people indiscriminately and definite reasons [23].

DarusSunnah Madrasa also uses a curriculum that teaches moderate attitudes and avoids radical thinking that leads to terrorist behavior. This was reflected in the Citizenship-based religious education which included religious education based on the yellow book, religious education based on science and technology, religious education based on Indonesian arts and culture, foreign language education (Arabic and English), guidance on scientific work, and extracurricular education. With a curriculum like this, the ideology of the Caliphate against the democratic system of the Indonesian state will be eroded. One of the factors causing radicalism is the influence of transnational Islamic movements such as the Ikhwan al-Muslimin, Hizbut-Tahrir, Saudi Arabia Wahhabism, Taliban Islam, and Al-Qaeda, all of which aspire to uphold Islamic Sharia in all areas of life.

\section{F. Learning Methods}

Ma'had 'Ali DarusSunnah uses the Sorogan learning method which is very thick with the world of pesantren, especially those that use the yellow book as the main learning tool. By using the Sorogan method, each student has the opportunity to learn directly with teachers who are experts in their fields, the teacher has a great opportunity to guide students effectively to improve academic quality.

The Sorogan System is students actively deliver the material they want to learn to the teacher so that he gets guidance specifically. The Sorogan System can instil moderate thinking because indoctrinated people are people who hold firmly to their control beliefs to produce ideological totalism[24].

DarusSunnah Madrasa uses discussion learning methods to instil inclusivism in thought and avoid the doctrine of a single truth in opinion. One of the factors causing radicalism is excessive punishment in terms of a single principle of belief and knowledge.

\section{G. Planting Character}

The character that Ali Mustafa developed through the ma'had 'ali and DarusSunnah madrasa to students was Islamic and Indonesian. This can be reflected in the culture of dress that he emphasizes to students. He did not consider Indonesian Muslims to dress like the clothes of the prophet in the Arab region with robes and other attributes. In his view, Islam only provides the concept of dressing with four provisions, namely: 1) not opening genitals; 2) not transparent; 3) not strict; and 4) do not resemble the clothes of the opposite sex. Therefore, every Muslim can use any type and model of clothing as long as it does not cross the above restrictions, even further, he asserted that dressing using traditional clothing from the area of origin and the area of residence, such as batik or koko for Indonesian people is better instead of using robe clothing, because it can eliminate the show off element in dressing. Of course, for the Arab community, it is better to dress the robe-like Arabic culture [25].

This view is inseparable from the religious background of the NahdlatulUlama group which strongly accommodates local cultures and traditions that grow in the midst of the surrounding community, then transforms Islamic values through four characters, namely moderate (Tawassut), balanced between a ratio and text approach (Tawāzun), straight (I'tidāl) and tolerant (Tasāmuḥ) [26].

\section{H. Teacher}

Educators are the main element of the output direction of an educational institution. Educators are elements that have a strong dominance to instil ideology in students. Therefore, DarusSunnah has a special qualification to choose educators who have the character of Islamic tradition and anti-radicalism. To maintain a positive social identity, individuals tend to prioritize their group (ingroup) compared to other groups (outgroup).

With the existing qualifications, DarusSunnah can provide strong control over the continuity of learning in Ma'had 'Ali and Madrasa with the presence of educators who act as facilities to educate students, as well as being anti-virus towards ideological understanding spread by radical groups outside the institution. education.

\section{ACKNOWLEDGMENT}

The conclusion of this research is the role of ulama through religious education institutions or Islamic boarding schools, madrasa, and ma'hadali in preventing radical understanding and movement is very important because the government needs figures who are close to the social community and education world to break the radical network.

Ali Mustafa Yaqub through madrasa and ma'hadaliDarusSunnah has taken over this important role to fortify Indonesia's education world from radical understanding through four fields of education, namely curriculum, learning methods, character building, and educators. This has succeeded in instilling moderate values with profiles of alumni who can play an active role as moderators of moderate understanding in the community.

\section{REFERENCES}

[1] Hendropriyono, A.M., 2009. Terorisme: Fundamentalis Kristen, Yahudi dan Islam, Buku Kompas. Jakarta.

[2] Badan Nasional Penanggulangan Terorisme (BNPT), "Strategi Menghadapi Paham Radikalisme Terorisme - ISIS". Link: $\quad$ http://belmawa.ristekdikti.go.id/wpcontent/uploads/2016/12/Strategi-Menghadapi-PahamRadikalisme-Terorisme.pdf.

[3] Wuryanto., 2011. "Bahaya Radikalisme". ICRP. Link: http://icrp-online.com/2011/11/22/bahaya-radikalisme/.

[4] Muhammad Andika Putra, "Survei Wahid Institute: 11 Juta Orang Mau Bertindak Radikal" CNN Indonesia. Link: https://www.cnnindonesia.com/nasional/20170814172156-20234701/survei-wahid-institute-11-juta-orang-mau-bertindakradikal. 
Ristek: Jurnal Riset, Inovasi dan Teknologi Kabupaten Batang Vol. 1, No. 1:45-65.

[16] Halik, Abdul., 2016. Strategi Kepala Madrasah dan Guru Dalam Pencegahan Paham Islam Radikal di Madrasah Aliyah Negeri (MAN) Mamuju, Tesis Universtas Islam Negeri Alauddin Makasar. Makasar.

[17] Mahfudhon, Ulin Nuha., 2018. Biografi Kyai Ali Mustafa Yaqub, Meniti Dakwah di Jalan Sunnah, Maktabah DarusSunnah. Jakarta.

[18] Taher, Tarmizi., 2004. Aspiring for the Middle PathIslam: Religious Harmony in Indonesia, Center for the Study of Islam and Society. Jakarta.

[19] Azra, Azyumardi., 2010. "Islam Indonesia: Kontribusi pada Peradaban Global”, PRISMA Vol. 29, No. 4: 1-18.

[20] Yaqub, Ali Mustafa., 2015. Titik Temu Wahabi-NU, Maktabah Darus-Sunnah. Jakarta.

[21] Hasbillah, Ahmad Ubaydi., 2017. Wawancara pada 20 November.

[22] Al-Bukhārī, Muḥammad ibn Ismā‘̄il., 2002. Șahịḥ̣ alBukhārī, Dār Ṭūq al-Najāh. Beirut.

[23] Yaqub, Ali Mustafa., 2016. Islam is not only for Muslims, Maktabah Darus-Sunnah. Ciputat.

[13] Fatihunnada., 2015. "Fahm al-Harakah al-Mutațarrifah li alSunnah al-Nabawiyyah", Kitāb al-Mu'tamar al-Dawlī: AlWasațiyyah Asās al-Khayriyyah, Muḥāwalah li Rasm Ma'ālim al-Fikr al-Islāmī fì Daw al-Tahaddiyyāt alMu’āṣirah, Universitas Islam Negeri Syarif Hidayatullah Jakarta. Jakarta.

[14] Badan Nasional Penanggulangan Terorisme (BNPT), "Strategi Menghadapi Paham Radikalisme Terorisme - ISIS". Link: $\quad$ http://belmawa.ristekdikti.go.id/wpcontent/uploads/2016/12/Strategi-Menghadapi-PahamRadikalisme-Terorisme.pdf.

[15] Muhtarom, Ali., 2016. "Peran Ulama dalam Menangkal Radikalisme Agama di Kabupaten Batang Jawa Tengah",
[24] Tan, Charle., 2011. Islamic Education and Indoctrinatien: The Case in Indonesia, Routladge. London.

[25] Yaqub, Ali Mustafa., 2016. Islam is not only for Muslims, Maktabah Darus-Sunnah. Ciputat.

[26] Effendi, Djohan., 2010. Pembaruan Tanpa Membongkar Tradisi: Wacana Keagamaan di Kalangan Generasi Muda NU Masa Kepemimpinan Gusdur, Kompas. Jakarta. 